\title{
Tribal Medicinal Plants: Documentation of Medicinal Plants Used by a Mogh Tribal Healer in Bandarban District, Bangladesh
}

\author{
Mohammed Rahmatullah ${ }^{1 *}$, Khoshnur Jannat ${ }^{1}$, Nusratun Nahar ${ }^{2}$, Rahat Al-Mahamud $^{1}$, Rownak Jahan ${ }^{1}$ and \\ Abdul Hamid ${ }^{3}$ \\ ${ }^{1}$ Department of Biotechnology \& Genetic Engineering, University of Development Alternative, Bangladesh \\ ${ }^{2}$ Department of Pharmacy, University of Development Alternative, Bangladesh \\ ${ }^{3}$ Agrarian Research Foundation, Bangladesh
}

*Corresponding author: Mohammed Rahmatullah, Dean, Faculty of Life Sciences,

University of Development Alternative, Lalmatia, Dhaka-1207, Bangladesh.

Received Date: July 05, 2019

Published Date: July 12, 2019

\begin{abstract}
Chittagong Hill Tracts region in the southeast portion of Bangladesh is considered a hotspot for medicinal plants. This hilly forested region is inhabited by a number of tribal communities, both large and small, and who still rely on their age-old traditional medicinal practitioners (TMPs) and their mainly phytotherapeutic practices for treatment and cure of various diseases. Since many important allopathic drugs have been discovered through documentation and studies of medicinal plants used by indigenous and tribal people, it was the objective of the present study to document the medicinal plants used by a Mogh (also called Marma) TMP, who claimed his original arrival in Bangladesh from Myanmar several decades ago. Information on ten plants was obtained from the TMP. The plants were distributed into ten families. The TMP used the plants to treat various disorders like tumor, gastrointestinal disorders, paralysis, pain, fever, convulsions, leucorrhea, and antidote to poisoning and as a muscle relaxant. Tumor, paralysis and convulsions (the latter may be due to epilepsy) are serious disorders. Gastrointestinal disorders can be chronic in Bangladesh and so needs effective treatment, which is also affordable. The medicinal plants used by the TMP merit scientific attention because further research can lead to discovery of lead compounds and new drugs.
\end{abstract}

Keywords: Mogh; Tribal healer; Medicinal plants; Chittagong hill tracts; Phytotherapy

\section{Introduction}

Plants have possibly been used as drugs by human beings since their very advent. For one, plants are plentiful and were easily available to early hominids; they may have discovered the therapeutic efficacy of plants through trial and error or through watching the behavior of the great apes and monkeys. For instance, wild chimpanzees in Uganda have been reported to ingest plants with bioactive properties including effectiveness against skin infections and intestinal parasites [1]. The same phenomenon has been observed with wooly spider monkeys inhabiting Intervales State Park in Brazil [2]. Many phytochemicals are currently being used as drugs in modern medicine and others are waiting for approval [3]. Some of these phytochemicals are taxol, vinblastine, vincristine, quinine, artemisinin, curcumin, silibinin, ellagic acid, and withaferin A. Traditional medicines can be utilized in the discovery of allopathic drugs. In one study, out of 122 modern drugs, $80 \%$ were found to be related to folk medicine and these compounds originated from 94 plant species [4]. However, to learn from traditional medicinal systems one has to visit practitioners of those systems for there are many variants of traditional medicinal systems in various countries. Even in a small country (in area) like Bangladesh, a number of forms of traditional medicinal systems exist, the three most predominant ones being Ayurveda, Unani and homeopathy. Two other forms of traditional medicinal systems also exist in Bangladesh, namely folk medicine and tribal medicine. Although both medicinal systems use plants as their main sources of therapy, selection of plants for any given disease varies widely between individual folk medicinal practitioners (FMPs) and individual tribal medicinal practitioners (TMPs). It is therefore 
important to document the practices of as many FMPs and TMPs as possible, because neither FMPs nor TMPs follow any fixed text books or manuals and do not need any formal training to practice.

Documentation of tribal medicinal practices requires ethnomedicinal survey of TMPs. The same applies to FMPs. Such surveys can not only lead to new drug discoveries, but also aids in the documentation and conservation of medicinal plants. We had been conducting such surveys for a number of years [5-26]. Although work has been done among various tribes of Bangladesh, much still remains to be completed. The Moghs (also known as Marmas) are the second largest tribal community inhabiting various areas of three districts of the Chittagong Hill Tracts (CHT) region in the southeast part of Bangladesh. They reside mainly in hilly forested parts of Bandarban, Khagrachari and Rangamati districts. They are descendants of the Arakanese people who lived in the Arakan region of neighboring Myanmar and settled in Tripura State of India and CHT possibly in the 16th century. The objective of the present survey was to document the phytotherapeutic practices of a Mogh TMP.

\section{Methods}

The Mogh tribal healer named Ong Thoai Ching practiced among the Mogh tribal community residing in Bandarban town of Bandarban district and adjoining areas, Bangladesh. Bandarban district is located in between in between $21^{\circ} 11^{\prime}$ and $22^{\circ} 22^{\prime}$ north latitudes and in between $92^{\circ} 04^{\prime}$ and $92^{\circ} 41^{\prime}$ east longitudes with an area of $4479.03 \mathrm{sq} \mathrm{km}$. The TMP was male, around 50 years of age (estimated, he did not mention his age) and practicing by his own admission for over 20 years. The TMP claimed to have arrived

Table 1: Plants and formulations of the Mogh TMP.

\begin{tabular}{|c|c|c|c|c|c|}
\hline Serial Number & Scientific Name & Family Name & Local Name & Parts Used & Ailments Treated \\
\hline 1 & $\begin{array}{l}\text { Colocasia esculenta (L.) } \\
\text { Schott }\end{array}$ & Araceae & Kochu & Tuber & $\begin{array}{l}\text { Heals tumor. Mixture of tuber of Colocasia } \\
\text { esculenta and ripe fruit of Musa sapientum } \\
\text { (wild variety) is orally taken. }\end{array}$ \\
\hline 2 & $\begin{array}{l}\text { Diospyros peregrina } \\
\text { (Gaertn.) Gurke }\end{array}$ & Ebenaceae & Choto Gab & Root & $\begin{array}{c}\text { Abdominal pain, diarrhea. Root of the plant } \\
\text { is macerated and orally taken with rice } \\
\text { washed water. }\end{array}$ \\
\hline 3 & Bauhinea purpurea L. & Fabaceae & Moha kanchon & Leaf & $\begin{array}{l}\text { Stimulant, increasing strength. Leaves of } \\
\text { the plant are orally taken as leafy vegetable. }\end{array}$ \\
\hline 4 & $\begin{array}{l}\text { Cissampelos hexandra } \\
\text { Roxb. }\end{array}$ & Menispermaceae & Tongrao & Whole plant & $\begin{array}{c}\text { Relief from acidity, abdominal pain. Juice } \\
\text { obtained from crushed whole plant is taken } \\
\text { orally. }\end{array}$ \\
\hline 5 & Moringa oleifera Lam. & Moringaceae & Sajna & Leaf & $\begin{array}{l}\text { Paralysis. Leaves of Moringa oleifera are } \\
\text { orally taken as vegetable; fried leaves are } \\
\text { also orally taken. Leaves of Moringa oleifera } \\
\text { and fruits of Piper nigrum are macerated } \\
\text { together to obtain juice. The juice is orally } \\
\text { taken 3-4 times per day. Alternatively, the } \\
\text { juice is made into chutney (sauce) and } \\
\text { orally taken. }\end{array}$ \\
\hline 6 & Musa sapientum L. & Musaceae & Kola & Ripe fruit & See Colocasia esculenta. \\
\hline 7 & Piper nigrum L. & Piperaceae & Golmorich & Fruit & See Moringa oleifera. \\
\hline 8 & $\begin{array}{l}\text { Prunus amygdalus } \\
\text { Batsch. }\end{array}$ & Rosaceae & Badam & Root, Bark & $\begin{array}{l}\text { Muscle relaxant, fever. Juice obtained from } \\
\text { root is rubbed as muscle relaxant. Juice } \\
\text { is orally taken to cure fever. Waist pain, } \\
\text { leucorrhea, and convulsion. Bark is boiled } \\
\text { in water and the water is orally taken. }\end{array}$ \\
\hline
\end{tabular}
settle on the outskirts of Bandarban town where it appeared he was quite well known among both Marma (Mogh) and Bawm tribal communities. Contact was initiated with the TMP through three Mogh and one Bawm community member known to one of the authors (AH). Prior informed consent was initially obtained from the TMP. The TMP was informed as to the nature of our visit and consent obtained to disseminate any information provided including their names both nationally and internationally. Actual interviews were conducted in the Bengali language, which was spoken fluently by the TMP (however with a heavy accent) as well as the interviewers. The interviews were conducted with the help of a semi-structured questionnaire and the guided field-walk method of Martin [27] and Maundu [28]. In this method the TMP took the interviewers to his home garden, where he cultivated a substantial number of medicinal plants for therapeutic purposes. The TMP showed the interviewers a number of plants and described their therapeutic uses. All plant specimens shown by him were collected on the spot, pressed, dried and brought back to Dhaka for identification by a competent botanist. Voucher specimens were deposited with the Medicinal Plant Collection Wing of the University of Development Alternative.

\section{Results and Discussion}

The TMP showed the authors ten plants, which he used frequently. The plants were distributed into ten families. The TMP used the plants to treat various disorders like tumor, gastrointestinal disorders, paralysis, pain, fever, convulsions, leucorrhea, and antidote to poisoning and as a muscle relaxant. The results are shown in Table 1. in Bangladesh from Myanmar about 30 years ago and decided to 


\begin{tabular}{|c|c|c|c|c|c|}
\hline 9 & $\begin{array}{c}\text { Mitragyna parvifolia } \\
\text { (Roxb.) Korth }\end{array}$ & Rubiaceae & Thei & Root & $\begin{array}{c}\text { Fever, body ache. Roots are boiled in water } \\
\text { to obtain juice. For excessive fever the juice } \\
\text { is orally taken and for body ache juice is } \\
\text { rubbed over the whole body. }\end{array}$ \\
\hline 10 & Datura metel L. & Solanaceae & Kalo dhutura & Seed & $\begin{array}{c}\text { Neutralizing poison. Seeds are warmed and } \\
\text { orally taken. }\end{array}$ \\
\hline
\end{tabular}

Of the various plants, three plants namely Cissampelos hexandra, Prunus amygdalus, and Mitragyna parvifolia appears to be plants rarely used in ethnomedical practices of Bangladesh. C. hexandra is a synonym of Stephania hernandiifolia (Willd.) Walp. Tribals in Jalpaiguri district, West Bengal, India use the roots of the plant to treat urinary diseases [29]; the TMP used the plant for acidity and abdominal pain. Fruits of P. amygdalus are considered in Unani medicine to be memory enhancer and nervine stimulant [30]; the TMP used root and bark as muscle relaxant and to treat fever. The plant is not a common plant in Bangladesh; the TMP might have grown the plant especially in his home garden. The Tharu tribe of India use leaves of M. parvifolia in hemorrhoids, colic, flatulence, dyspepsia, myalgia, fever, skin diseases, wounds and ulcers; bark and roots in fever, colic, muscular pains, burning sensations in the stomach, coughs, edema and blood disorders [31]. The TMP used the roots of this plant for fever and body ache. Anti-inflammatory and anti-nociceptive properties of ethanolic extract of dried leaves of the plant have been reported [32].

Interestingly, the tubers of Colocasia esculenta were claimed by the TMP to heal tumors. A tumor was defined by the TMP to be abnormal swelling without pain in the external surface of the body. Anti-metastatic effects and anti-cancer effects on colonic adenocarcinoma cells in vitro have been reported [33, 34]. Leaves of Moringa oleifera were used by the TMP to treat paralysis. Hemispheric cerebral ischemia due to the occlusion of middle cerebral artery develops contralateral paralysis and sensory loss, leaf extract of the plant has been reported to give cerebroprotective effect [35].

\section{Conclusion}

Although the number of plants provided by the TMP was limited, the plants appear to merit considerable potential for further scientific research as to their pharmacological activities and phytochemical(s) identification, which in turn can lead to discovery of lead compounds and efficacious drugs.

\section{Acknowledgement}

The authors are grateful to the Mogh TMP for providing information on his phytotherapeutic practices.

\section{Conflict of Interest}

The authors declare that there are no conflicts of interest.

\section{References}

1. Krief S, Hladik CM, Haxaire C (2005) Ethnomedicinal and bioactive properties of plants ingested by wild chimpanzees in Uganda. J Ethnopharmacol 101(1-3): 1-15.

2. Petroni LM, Huffman MA, Rodrigues E (2017) Medicinal plants in the diet of wooly spider monkeys (Brachyteles arachnoids, E. Geoffroy,
1806) - a bio-rationalfor the search of new medicines for human use? Brazilian J Pharmacogn 27(2): 135-142.

3. Shakya AK (2016) Medicinal plants: Future source of new drugs. Int J Herbal Med 4(4): 59-64.

4. Fabricant DS, Farnsworth NR (2001) The value of plants used in traditional medicine for drug discovery. Environ Health Perspect 109 (Suppl 1): 69-75.

5. Rahmatullah M, Ferdausi D, Mollik MAH, Jahan R, Chowdhury MH, et al. (2010) A Survey of Medicinal Plants used by Kavirajes of Chalna area, Khulna District, Bangladesh. Afr J Tradit Complement Alternat Med 7(2): 91-97.

6. Rahmatullah M, Khatun MA, Morshed N, Neogi PK, Khan SUA, et al. (2010) A randomized survey of medicinal plants used by folk medicinal healers of Sylhet Division, Bangladesh. Adv Nat Appl Sci 4(1): 52-62.

7. Rahmatullah M, Kabir AABT, Rahman MM, Hossan MS, Khatun Z, et al. (2010) Ethnomedicinal practices among a minority group of Christians residing in Mirzapur village of Dinajpur District, Bangladesh. Adv Nat Appl Sci 4(1): 45-51.

8. Rahmatullah M, Momen MA, Rahman MM, Nasrin D, Hossain MS, et al. (2010) A randomized survey of medicinal plants used by folk medicinal practitioners in Daudkandi sub-district of Comilla district, Bangladesh. Adv Nat Appl Sci 4(2): 99-104.

9. Rahmatullah M, Mollik MAH, Ahmed MN, Bhuiyan MZA, Hossain MM, et al. (2010) A survey of medicinal plants used by folk medicinal practitioners in two villages of Tangail district, Bangladesh. Am Eur J Sustain Agric 4(3): 357-362.

10. Rahmatullah M, Mollik MAH, Islam MK, Islam MR, Jahan FI, et al. (2010) A survey of medicinal and functional food plants used by the folk medicinal practitioners of three villages in Sreepur Upazilla, Magura district, Bangladesh. Am Eur J Sustain Agric 4(3): 363-373

11. Rahmatullah M, Jahan R, Khatun MA, Jahan FI, Azad AK, et al. (2010) A pharmacological evaluation of medicinal plants used by folk medicinal practitioners of Station Purbo Para Village of Jamalpur Sadar Upazila in Jamalpur district, Bangladesh. Am Eur J Sustain Agric 4(2): 170-195.

12. Rahmatullah M, Ishika T, Rahman M, Swarna A, Khan T, et al. (2011) Plants prescribed for both preventive and therapeutic purposes by the traditional healers of the Bede community residing by the Turag River, Dhaka district. Am Eur J Sustain Agric 5(3): 325-331.

13. Rahmatullah M, Azam MNK, Rahman MM, Seraj S, Mahal MJ, et al. (2011) A survey of medicinal plants used by Garo and non-Garo traditional medicinal practitioners in two villages of Tangail district, Bangladesh. Am Eur J Sustain Agric 5(3): 350-357.

14. Rahmatullah M, Biswas KR (2012) Traditional medicinal practices of a Sardar healer of the Sardar (Dhangor) community of Bangladesh. J Altern Complement Med 18(1): 10-19.

15. Rahmatullah M, Hasan A, Parvin W, Moniruzzaman M, Khatun A, et al. (2012) Medicinal plants and formulations used by the Soren clan of the Santal tribe in Rajshahi district, Bangladesh for treatment of various ailments. Afr J Tradit Complement Alternat Med 9(3): 350-359.

16. Rahmatullah M, Khatun Z, Hasan A, Parvin W, Moniruzzaman M, et al. (2012) Survey and scientific evaluation of medicinal plants used by the Pahan and Teli tribal communities of Natore district, Bangladesh. Afr J Tradit Complement Alternat Med 9(3): 366-373.

17. Rahmatullah M, Azam MNK, Khatun Z, Seraj S, Islam F, et al. (2012) Medicinal plants used for treatment of diabetes by the Marakh sect of the Garo tribe living in Mymensingh district, Bangladesh. Afr J Tradit Complement Alternat Med 9(3): 380-385. 
18. Rahmatullah M, Khatun Z, Barua D, Alam MU, Jahan S, et al. (2013) Medicinal plants used by traditional practitioners of the Kole and Rai tribes of Bangladesh. J Altern Complement Med 19(6): 483-491.

19. Rahmatullah M, Pk SR, Al-Imran M, Jahan R (2013) The Khasia tribe of Sylhet district, Bangladesh, and their fast-disappearing knowledge of medicinal plants. J Altern Complement Med 19(7): 599-606.

20. Akter S, Nipu AH, Chyti HN, Das PR, Islam MT, et al. (2014) Ethnomedicinal plants of the Shing tribe of Moulvibazar district, Bangladesh. World J Pharm Pharmaceut Sci 3(10): 1529-1537.

21. Azad AK, Mahmud MR, Parvin A, Chakrabortty A, Akter F, et al. (2014) Medicinal plants of a Santal tribal healer in Dinajpur district, Bangladesh. World J Pharm Pharmaceut Sci 3(10): 1597-1606.

22. Azad AK, Mahmud MR, Parvin A, Chakrabortty A, Akter F, et al. (2014) Ethnomedicinal surveys in two Mouzas of Kurigram district, Bangladesh. World J Pharm Pharmaceut Sci 3(10): 1607-1620.

23. Kamal Z, Bairage JJ, Moniruzzaman, Das PR, Islam MT, et al. (2014) Ethnomedicinal practices of a folk medicinal practitioner in Pabna district, Bangladesh. World J Pharm Pharmaceut Sci 3(12): 73-85.

24. Anzumi H, Rahman S, Islam MA, Rahmatullah M (2014) Uncommon medicinal plant formulations used by a folk medicinal practitioner in Naogaon district, Bangladesh. World J Pharm Pharmaceut Sci 3(12): 176-188.

25. Esha RT, Chowdhury MR, Adhikary S, Haque KMA, Acharjee M, et al. (2012) Medicinal plants used by tribal medicinal practitioners of three clans of the Chakma tribe residing in Rangamati district, Bangladesh. Am Eur J Sustain Agric 6(2): 74-84.

26. Malek I, Miah MR, Khan MF, Awal RBF, Nahar N, et al. (2014) Medicinal plants of two practitioners in two Marma tribal communities of Khagrachhari district, Bangladesh. Am Eur J Sustain Agric 8(5): 78-85.
27. Martin GJ (1995) Medicinal Plants in the Ethno Veterinary Practices of Bensa Woreda, Southern Ethiopia. In: Ethnobotany: a 'People and Plants' Conservation Manual, Chapman and Hall, London, pp. 268.

28. Maundu P (1995) Methodology for collecting and sharing indigenous knowledge: a case study. Indigenous Knowledge and Development Monitor 3(2): 3-5.

29. Bose D, Roy JG, Mahapatra (Sarkar) SD, Datta T, Mahapatra SD, et al. (2015) Medicinal plants used by tribals in Jalpaiguri district, West Bengal, India. J Med Plants Stud 3(3): 15-21.

30. Masihuddin, Jafri MA, Siddiqui A, Khan A (2018) Phytochemistry, pharmacological activities and traditional uses of Prunus amygdalus with special reference of Unani medicine: An updated review. Int J Sci Res Rev 7(11): 83-92.

31. Bajpai O, Pandey J, Chaudhary LB (2016) Ethnomedicinal uses of tree species by Tharu treibes in the Himalayan Terai region of India. Res J Med Plant 10(1): 19-41.

32. Gupta V, Kumar P, Bansal P, Singh R (2009) Anti-inflammatory and antinociceptive activity of Mitragyna parvifolia. Asian J Med Sci 1(3): 97-99.

33. Kundu N, Campbell P, Hampton B, Lin CY, Ma X, et al. (2012) Antimetastatic activity isolated from Colocasia esculenta (taro). Anticancer Drugs 23(2): 200-211.

34. Brown AC, Reitzenstein JE, Liu J, Jadus MR (2005) The anti-cancer effects of poi (Colocasia esculenta) on colonic adenocarcinoma cells In vitro. Phytother Res 19(9): 767-771.

35. Kirisattayakul W, Wattanathorn J, Tong-Un T, Muchimapura S, Wannanon P, et al. (2013) Cerebroprotective effect of Moringa oleifera against focal ischemic stroke induced by middle cerebral artery occlusion. Oxid Med Cell Longev: 951415. 